\title{
Three - Dimensional (3-D) video imaging as a tool in pre-operative evaluation of head and neck tumors
}

\author{
Masrin Munir
}

\begin{abstract}
Abstrak
Suatu tehnik baru pemeriksaan tomografi komputer, yaitu pemeriksaan dengan tomografi helikal atau spiral, memungkinkan seluruh bagian dari kepala dan leher dapat diperiksa dengan cepat (30 detik). Walaupun dengan tomografi komputer biasa, dapat diperoleh gambaran 3 dimensi, isi atau rongga yang terlihat pada komputer yang berputar memberikan suatu gambaran yang mudah dianalisa untuk tindakan selanjutnya. Gambaran yang didapat dari komputer 3-dimensi, digunakan oleh para ahli radiologi dan ahli THT untuk mengetahui 1) kualitas gambar 2) perluasan dari tumor 3) memahami lesi yang ada dan membandingkannya dengan hasil tomografi komputer biasa. Seorang penderita laki-laki berumur 32 tahun dengan tumor pada mandibula kiri sejak 15 tahun, akan dilakukan tindakan operasi. Tomografi komputer kepala beserta gambar-gambar yang diperoleh dari video 3-dimensi yang berputar, dibuat sebelum pengangkatan massa tumor. Dari hasil rekonstruksi gambar-gambar tomografi komputer berputar, terlihat dengan jelas adanya suatu massa yang besar dengan beberapa lubang didalamnya, serta penipisan dinding mandibula. Pada waktu operasi, suatu massa yang besar yang mengisi sebagian mandibula kiri diangkat keseluruhannya, sedangkan bagian pinggir mandibula yang masih intak ditinggalkan. Hasil pemeriksaan histopatologik menunjukkan suatu ameloblastoma.
\end{abstract}

\begin{abstract}
A new computed tomography (CT) technology, by means of helical (spiral) CT, allows the entire head and neck to be imaged in only 30 seconds. Although multiplanar and three-dimensional (3-D) imaging could be performed with conventional CT, the volumetric aquisition provided by helical (spiral) CT allows an easier reconstruction for further applications. Independent review of the 3-D images by radiologist and otolaryngologist was performed to assess 1) the image quality 2) the expansion of tumor 3) the interprentation of the lesion compared to that provided by routine axial scans. A 32-year old male patient with a tumor of left mandible since 15 years was scheduled for operation. CT scan of the head and three-dimensional (3-D) video imaging were done before surgical treatment of the tumor. After reconstruction of the helical (spiral) CT, it was shown that the tumor has a large expansive (with holes) multilocular abnormality with cortical thinning of left mandible. On operation, a large tumor occupying left mandible was completely removed, while the margin of the mandible still remained. The histopathological finding revealed an ameloblastoma.
\end{abstract}

Keywords : Three-dimensional video imaging, ameloblastoma, helical tomography

The introduction of conventional computed tomography (CT) scanning has had a major impact on evaluating inflammation or neoplastic masses of the head and neck. This conventional CT has some limitations, such as blurring of images caused by patient motion, breathing or swallowing. Most recently, the introduction of helical (spiral) CT has dramatically changed the ability to image the structure of the head and neck. A large mass on the left mandible in a patient of 32-year of age was detected by conventional CT scan and (3-D) video imaging. From the histological finding, it shows that the tumor is ameloblastoma.

Department of Otorhinolaryngology, Faculty of Medicine, University of Indonesia/Dr. Cipto Mangunkusumo Hospital, Jakarta. Indonesia
Ameloblastoma is the most common epithelial odontogenic tumors. It was recognized by Cuzak in 1827 as quoted by Mc Daniel RK.' Other experts said ameloblastoma as adamantinoma, adamanblastoma, basiloma or epithelioma ameloblastoides.

The most common symptoms of ameloblastoma are a slow growing tumor, painless swelling and the diagnosis is often delayed. Other manifestations which are less common, include mobile teeth, ill fitting dentures, malocclusion, ulcerations, nasal obstruction and others. The size of ameloblastomas may range from small, asymptomatic lesions measuring less than $1 \mathrm{~cm}$ up to a mass measuring as large as $15 \mathrm{~cm}$. Surgery is the mainstay of treatment, but local recurrence is high and the multicystic lesion has poorer prognosis. 


\section{Case report}

A 32-year of age male patient was admitted the Department of Otolaryngology, Dr. Cipto Mangunkusumo Hospital, University of Indonesia on November 5, 1997 with the chief complaint of a large mass on his left mandible, with $10 \times 8 \times 5 \mathrm{~cm}$ in size (Figure 1).

The patient was referred from Dharmais Cancer Center Hospital with a tumor in his left mandible since 15 years. The inferior left second premolar and two molar teeth were mobile and were extracted. One year later the tumor grew bigger, ruptured with bleeding. Four years after extracting the teeth, the tumor was resected by a general surgeon at Pangkal Pinang Hospital Sumatera. Two years later, recurrences occurred and the tumor became bigger.
General condition and other otolarynoglogical examination were within normal limits. No history of dyspnea, nor cough, nausea, vomiting, general fatique, anorexia or loss of weight. Laboratory findings were within normal limits. Conventional computerized tomography (CT) scanning with and without contrast of the head and neck, was done on October 24, 1997, with sagital and coronal section of $5 \mathrm{~mm}$ slices. The CT showed a dense mass at the angle of the left mandible. A wide destruction was noticed with thinning of the cortex of the mandible, but no empty space showed in the CT. A mass of $73.6 \times 66.3 \mathrm{~mm}$ with lateral enhancement was seen on the CT (Figure 2). Diagnosis of the tumor can not be made from the CT scan.

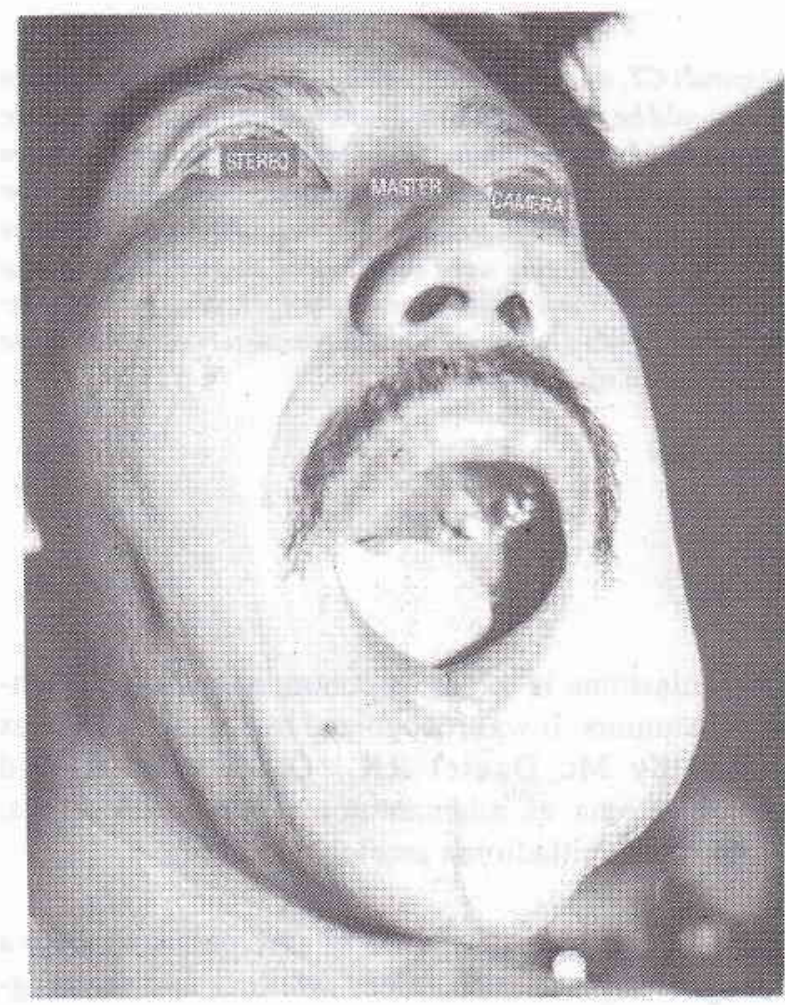

Figure 1. A 32-year male with a large mass on left mandible.

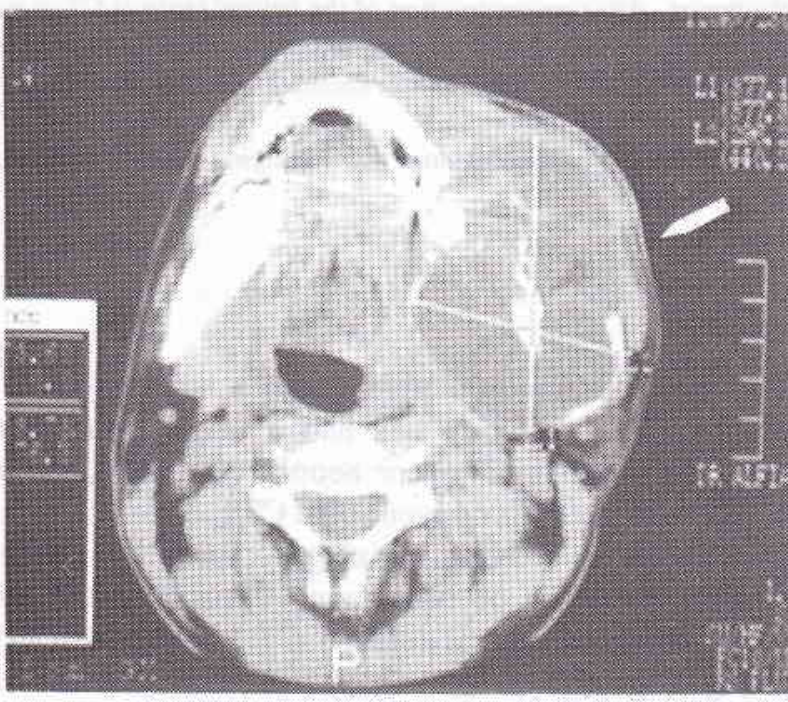

Figure 2. An axial plane of conventional CT scanning showed a large mass with cortical thinning on left mandible 
Biopsy was done on November 6 and November 12, 1997 with no tumor cell seen in the histological findings. On November 24, 1997 a three-dimensional (3D) imaging by means of helical (spiral) computed

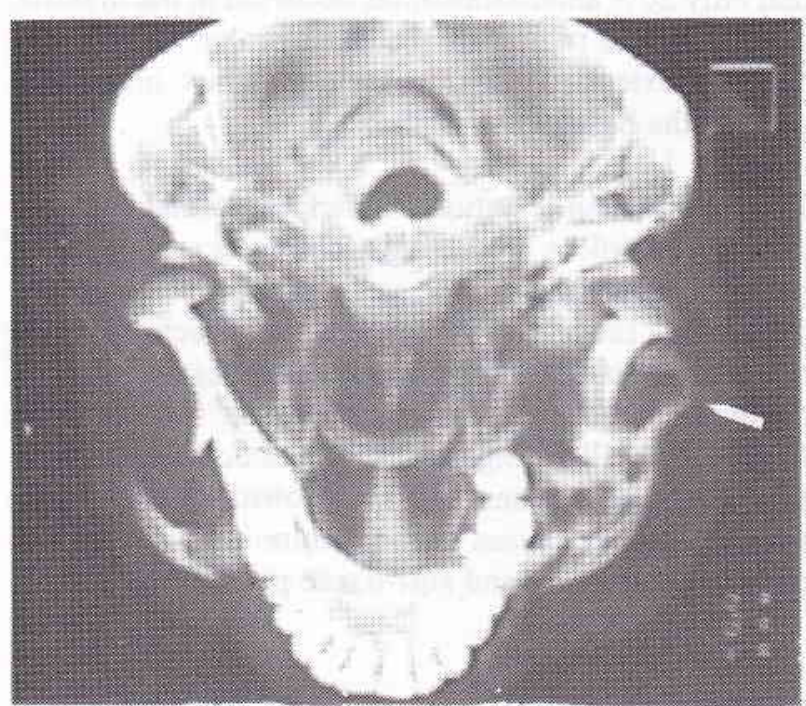

Figure 3. Caudal view of the head in a 3-D imaging of spiral CT showing enlarged left mandible, eroded with several holes in it.

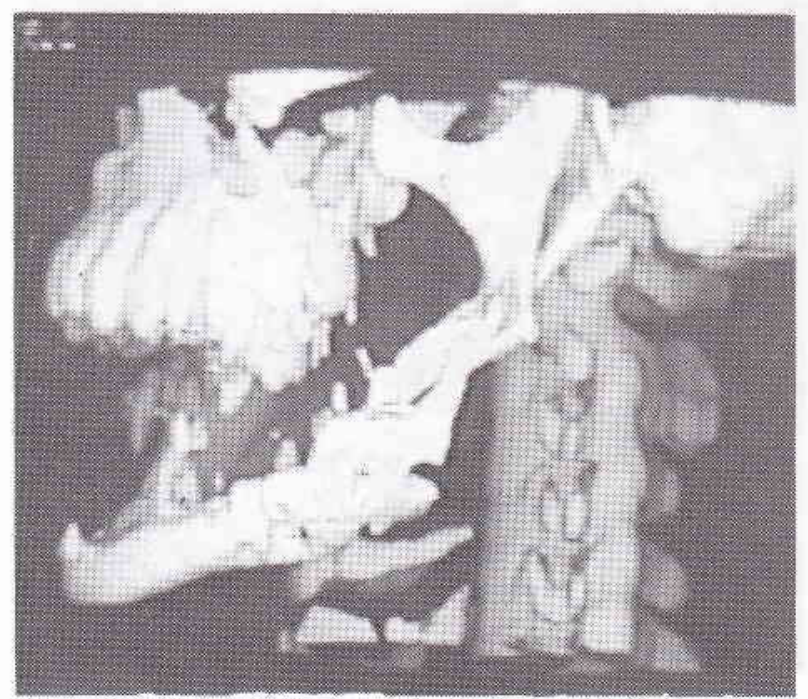

Figure 5. Left lateral view of the head from a 3-D imaging of spiral CT. tomography of the head and neck was done in another hospital. The helical (spiral) CT reconstruction showed a tumor on left mandible with separated holes in the tumor mass (Figures 3,4,5,6).

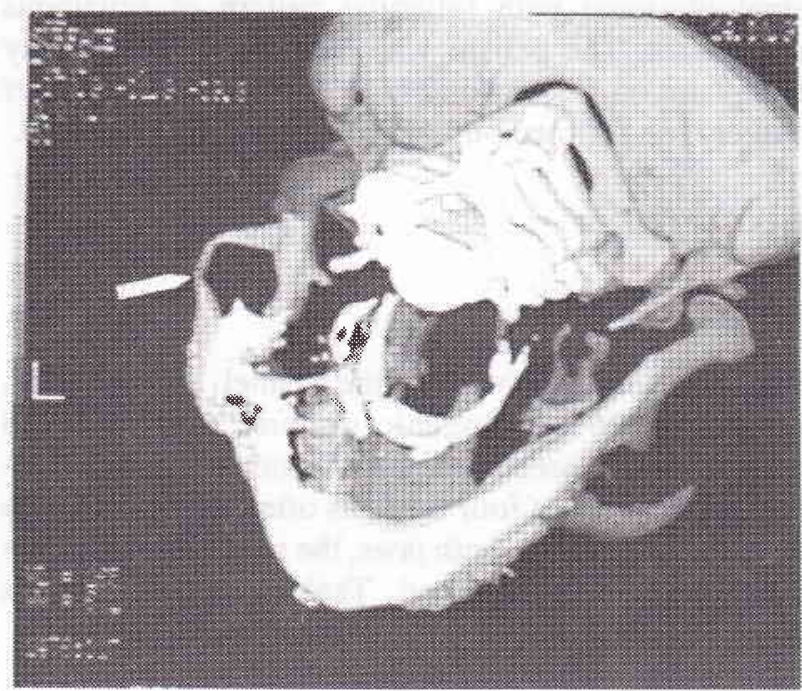

Figure 4. Proximal view of the head from a 3-D imaging of spiral CT showing enlarged mandible with the holes in the mass.

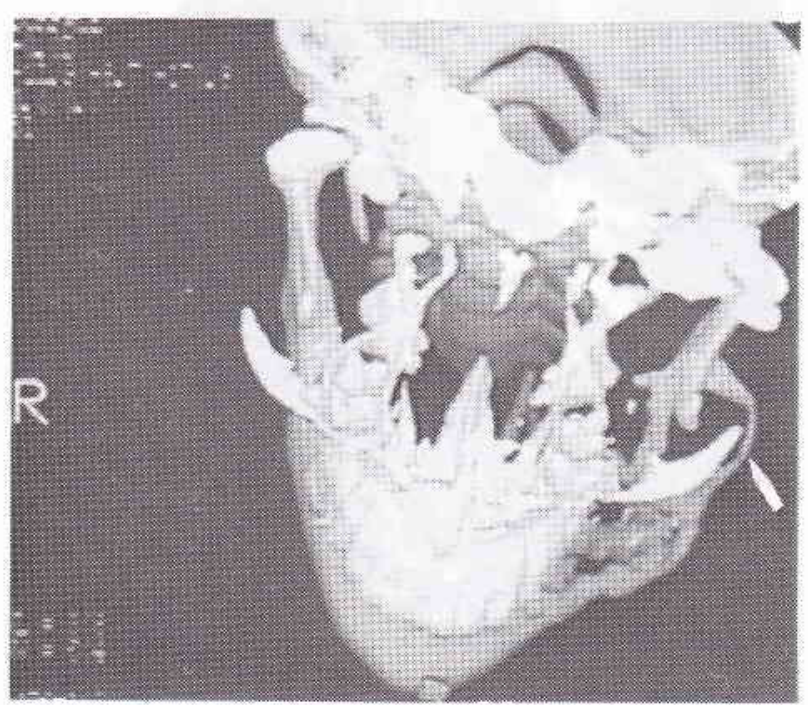

Figure 6. Anterior view of the head from a 3-D imaging of spiral CT. 
Surgical treatment of the tumor at the left mandible was done under general anesthesia on December 20 , 1997 with median submandibular incision approach. A multilocular cystic tumor of $7 \times 6 \times 4 \mathrm{~cm}$ in size was exenterated, followed by curretage the margin of the mandible (Figure 7).

The histological finding of the specimen revealed an ameloblastoma with follicular pattern of squamous metaplasia. The patient was discharged without any complaint on December 24, 1997. Three months after surgery, on followed-up, no recurrence was detected.

\section{DISCUSSION}

\section{Ameloblastoma}

Regezi et al as quoted by the Daniel $\mathrm{RK}^{1}$ in 1987 , reviewed 706 odontogenic tumors, with $11 \%$ (78 patients) composed of ameloblastomas. Ameloblastomas occur about four times as often in the mandible as in the maxilla. In both jaws, the posterior region are most commonly affected. Tsaknis and Nelson as

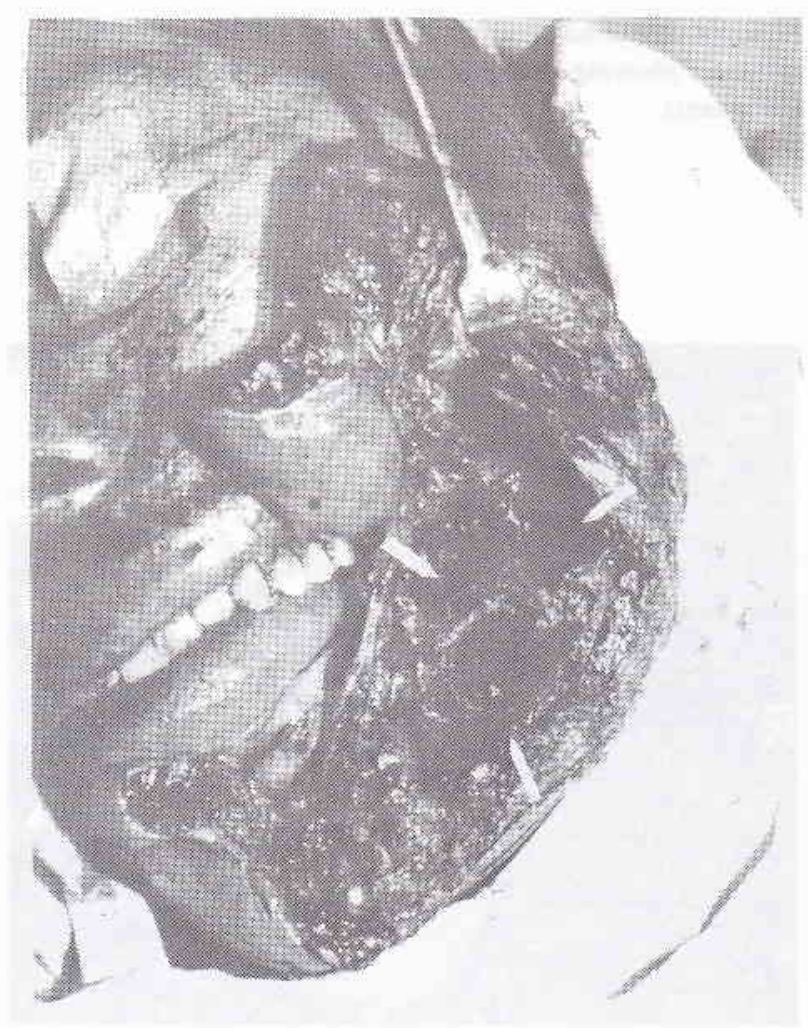

Figure 7. Median submandibular incision of the exenterated tumor. quoted by Mc Daniel RK claimed that of 24 maxillary ameloblastomas, $83 \%$ (20 patients) were located at the posterior part and the mean age was 45.6 years. Dierks EJ and Bernstein $\mathrm{ML}^{2}$ in 1993, claimed that ameloblastomas may be affected in all ages, but the peak occurrences were in the third and fourth decades (mean age 40 years). Miller R.H et $^{3} \mathrm{l}^{3}$ in 1996 quoted that only $20 \%$ ameloblastomas occurred in the maxilla, usually in the region of the third molar. They may however extended into the maxillary sinus, nose, orbit or even the base of the skull. ${ }^{4}$

The clinical manifestation of ameloblastomas is a slow growing, painless as the most common complaint of patients, even the tumor is in advanced stage. $5,6,7$ Typically, the early symptoms are absent and the tumors are difficult to be diagnosed in early stages of development. Other less common manifestations are mobile teeth, ill-fitting dentures, malocclusion, ulceration, draining sinuses and nasal obstruction. Large ameloblastoma causes cortical thinning, perforation, pathologic fracture and soft-tissue penetration.

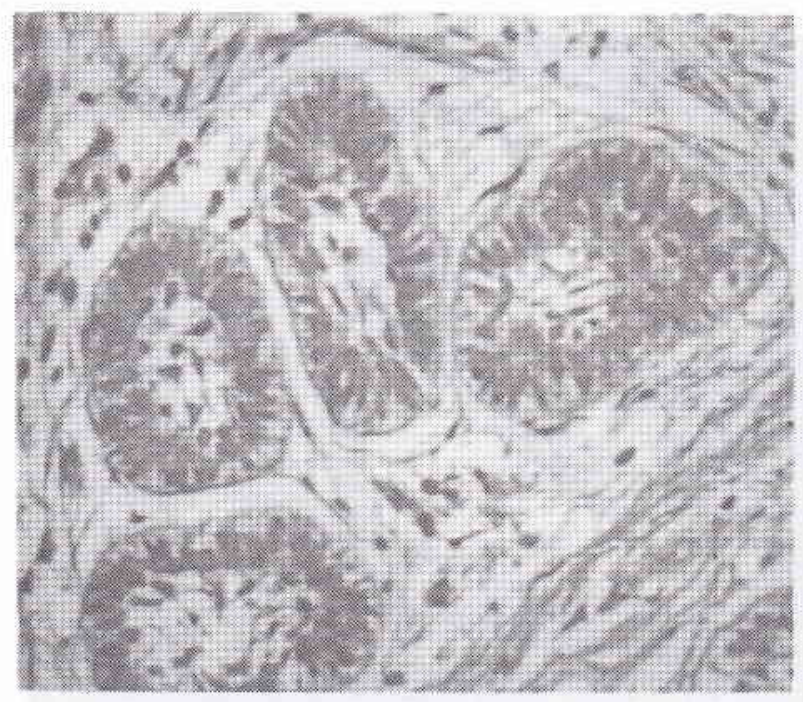

Figure 8. Histopathological finding showed ameloblastoma with follicular pattern of squamous metaplasia. 
Radiographically, the tumor is a multilocular lucency, with no calcified or radiopaque components. Other radiographic spectrum is that, the tumors may appear unilocular, with or without association with a tooth. Two predominant patterns of ameloblastoma are follicular and flexiform. ${ }^{7,8}$ of the two types, the follicular pattern is more common. Cystic degeneration may occur in the central stellate area of the follicles and also in the stroma. The recurrence rate for ameloblastomas treated by exenteration or curretage is reported to be 55 to 99 percent. ${ }^{1}$ Pinsolle $\mathrm{J}^{6}$ claimed that $41 \%$ of 40 patients, has local recurrences.

Large ameloblastomas cause cortical thinning and perforation, pathologic fracture and soft-tissue penetration. The treatment at the primary site for an established malignant ameloblastoma, should not differ from the complete excision for an infiltrating ameloblastomas. Cases which have been found to metastasize, retaining their benign histologic pattern, are called malignant ameloblastomas, while ameloblastoma which clinically and cytologically are malignant, are termed as ameloblastic carcinomas and on these cases appropriate radical resection should be undertaken.

\section{Three-dimensional (3-D) computed imaging}

The introduction of conventional tomography (CT) scanning has had a major impact on evaluating inflammatory and neoplastic masses in head and neck. The basic cross sectional of axial images is able to distinguish soft tissue density from fat and tumor invasion, deep to the mucosal surfaces. Most recently, the introduction of helical (spiral) CT has dramatically changed of ability to image the oral cavity, oropharynx, hypopharynx, larynx and upper airway. ${ }^{9}$ This differs from conventional $C T$ in that the patient is moved continuously through the CT Scanner during a continuous $\mathrm{x}$-ray exposure. ${ }^{10}$

The basic design for the 3-D system was developed at St. Louis University School of Medicine in conjunction with new Dimensional Communications Inc. St. Charles, MO. ${ }^{9}$ The 3-D imaging can rotate continuously along any axis of the airway to optimally assess disease. The goal of 3-D imaging is 1 . to evaluate the quality of the 3-D images, 2 . to evaluate to what degree these images assisted the radiologist and otolaryngologist in judging the lesion extend, relative to axial images 3 . to assess whether there is any difference between radiologists and otolaryngologists perceptions of the 3-D images. The technological ad- vances in video imaging over the last 10 years have resulted in remarkable additions to the tools of otolaryngologists. ${ }^{9,10}$ Currently, 3-D imaging is being used in a variety of otolaryngologist in head and neck procedures. ${ }^{11}$ This technique has also increased the number of surgeon ability to view the operative procedures as well as for permanent documentation of the procedures. $^{12}$

\section{CONCLUSION}

A 32-year of age male patient with a large recurrence mass of the left mandible, is reported. In this case, conventional CT scan and 3-D video imaging had been done. The 3-D video imaging showed, the ameloblastoma consists of multilocular tumor with septa and destruction of the left mandible, while the conventional CT scan only showed the extension of the tumor without septa. It seem that it is difficult to detect multilocular ameloblastoma by conventional CT scan. Although conventional CT-scan did not show a tumor with septa, this modality was necessary to have the information about the size and extension of the tumor. The histological finding of the tumor is ameloblastoma of follicular pattern. And showed the symptoms of slow growing, painless swelling with high local recurrences. This patient already treated for several times with exenteration of the tumor, but local recurrences occurred after surgical intervention. The last treatment was partial mandibulectomy and exenteration of the tumor without recurrence after 3 months. The tumor was located at the mandible as the most clinical feature of ameloblastoma while the radiographic feature of ameloblastoma is that of an expansive, multilocular radiolucence tumor. Clinical and radiological features are the same with that quoted by many experts.

\section{ACKNOWLEDGEMENT}

The author wishes to express his thank to Dr. Bambang Budyatmoko from the Radio-Diagnostic Sub Division, Department of Radiology, Faculty of Medicine, University of Indonesia, Dr. Cipto Mangukusumo Hospital, Jakarta, Indonesia to his explanation of the 3-D Video imaging photos in this article.

\section{REFERENCES}

1. Daniel RK. Odontogenic Cysts and Tumors Clinical evaluation and pathology. In : Thawley SE and Pantje WR (eds) Comprehensive management of Head and Neck Tumors. Philadelphia, London, Toronto, Mexico City, Rio de Janairo, Sydney, Tokyo, Hong Kong : W.B Saunders Company; 1987, p. $1446-63$. 
2. Dierks EJ, Bernstein ML. Odontogenic Cysts, Tumors and Related Jaw Lesions, In : Bailey BJ, Johnson JT, Kohut R.I Pillsburry III HC, Tardi ME(eds). Head and Neck Surgery Otolaryngology. Philadelphia : J.B. Lippincott Company, 1993. II, p. 1176 - 91.

3. Miller RH, Sturgis EM, Sutton CL. Neoplasms of the Nose and Paranasal Sinuses. In : Ballenger JJ, Snow JB (eds). Otorhinolaryngology Head and Neck Surgery. Baltimore, Philadelphia, Hong Kong, London, Munich, Sydney, Tokyo : Williams and Wilkins, A Waverly Company; 1996, p. 194 $-205$.

4. Montgomerry WW. Surgery of the maxillary sinus. In : Montgomerry WW (ed). Surgery of the Upper Respiratory System. Baltimore, Philadelphia, London, Paris, Bangkok, Buenos Aires, Hong Kong, Munich, Sydney, Tokyo, Wroclaw. Williams \& Wilkins; 1996, p.323 - 69.

5. Ballenger JJ. Diseases of the Oral Cavity. In : Ballenger JJ, Snow JB (eds). Otorhinolaryngology Head \& Neck Surgery. Baltimore, Philadelphia, Hong Kong, London, Munich, Sydney, Tokyo : Williams \& Wilkins, A Waverly Company; 1996, p.228 - 35 .

6. Pinsolle J, Michelet V, Coustal B, Siberchicot F-X, Xaver Michelet F. Treatment of Ameloblastoma of the Jaws. Arch Otolaryngol Head \& Neck Surg; 1995, 121 : 994 - 6.
7. Waldron C.A. Odontogenic Cysts and Tumors. In : Neville BW, Dam DD, Allan CM, Bouquot JE (eds). Oral \& Maxillo-facial Pathology. Philadelphia, London, Toronto, Montreal, Sydney, Tokyo : Saunder WB Company; 1995, p.511 - 70 .

8. Shah J.P. Bone Tumors (Tumors and Cysts of the Jaws). In : Shah JP (ed.). Head and Neck Surgery (2nd ed) Diagnostic Approaches, Therapeutic Decisions. Surgical Techniques and Results of Treatment. New York, Philadelphia, Milan, Boston, London : Mosby-Wolfe; 1996, p.523 - 52.

9. Maves MD, Cooper MH, Benecke JE, Young PH, Maas CS. Three-Dimensional Video Imaging in Otolaryngology Head and Neck Surgery. Laryngoscope 1993 ; 103 : 1174 -6.

10. Silverman PM, Zeiberg AS. Sessions RB, Troost TR, Zeman RK. Three-Dimensional Imaging of the Hypopharynx and Larynx by means of Helical (spiral) computed tomography. Ann Otol Rhinol Laryngol 1995 ; 104 : 425 - 31.

11. Tsunoda A, Komatsuzaki A, Yamada M, Terasaki O. ThreeDimensional Computed Imaging using a Personal Computer for Nasal Surgery. Laryngoscope 1996; 106 : 584 - 8.

12. Donnely KJ, Bank ER, Parks WJ, Gussack GS, Davenport P, Todd NW. Three-Dimensional Magnetic Resonance Imaging Evaluation of Pediatric Tracheobronchial Tree. Laryngoscope 1994 ; 104 : 1425 - 9. 